\title{
The Impact of High and Low Atmospheric Pressure in the Jordanian Environment on Some Physiological
Variable for Runners
}

\author{
Dr. Baker Sulaiman Thuneibat \\ Mutah University \\ Email: Ana_baker1980@yahoo.com
}

Doi:10.5296/jsr.v4i2.4358 URL: http://dx.doi.org/10.5296/jsr.v4i2.4358

\begin{abstract}
:
The study aimed at identifying the impact of difference between the areas of high atmospheric pressure in the Jordanian environment on some physiological variable ( estimating maximal oxygen consumption, estimating rate of Energy expenditure, and hemoglobin ,vital capacity), for runners .

The study sample consisted of (16) athletes who practice ( middle and long - distance running). A number of statistical methods were used to answer the questions of the study ( arithmetic means, standard deviations , Mann.Whiteny test , and the result of Kolmogorov Smirnov tests ).

The study result concluded that there was apriority for the measurements which were conducted on the training groups of low atmospheric pressure in comparison with the other group, with regard to the variables (maximal oxygen consumption, rate of Energy expenditure, and hemoglobin). The study result also showed that there was apriority for the measurements which were conducted on the training groups of high atmospheric pressure in comparison with the other group, regarding to the variables (maximal oxygen consumption, rate of Energy expenditure, and hemoglobin).in the areas of high atmospheric pressure.

The study result also suggested that ther were no statistically significant differences between two training groups with regard to the study variables of (maximal oxygen consumption, rate of Energy expenditure, and hemoglobin, vital capacity), were measured in of high atmospheric pressure areas.

The study recommended about building sports facilities that simulate the areas of low atmospheric pressure, because of the expected role that the factors would play in improving some physiological variables.
\end{abstract}

\section{Introduction}

The specialists in the field of ( science of sports training ) dedicated most of their writings about sports training in various conditions, due to the importance of tgis subject, as we know that practicing the sports activities takes place in different conditions. Some of these conditions may have an impact which is similar to the impact that takes place during 
competitions which were held in hot, cold, and rainy weather, or even in the area which are situated above sea level. thus the coaches have to prepare the athletes adequately in order to face such conditions so that the athletes have to get enough training to the condition that are similar to those of competitions.

The issue of living and training in places and cities that are located on high altitudes above sea level is completely related to adaption, by which the human being and his internal organ system is exposed to external effect that disrupt the relative internal balance . between the bioprocess which aim at maintaining this balance . therefore provokes the bio physiological processes in order to the balance to its natural condition and protect the body systems from the frequent exposure to this defect through the immune system . (Al-Borai, 2008)

When the human being ascends above sea level, the atmospheric pressure decreases and the molecular oxygen pressure also decreases, and that leads to a serious difficulty in breathing, through which the average rate of breathing increases, due to the body cells intensive need to oxygen in order to do their function,. If the oxygen wasn't enough because of the high altitude above sea level, the human being would suffer from a critical case through which his breathing is disturbed, because of the sharp decrease in the amount of oxygen and that leads to decrease in the ability of the respiratory system, (Ismail,2008)

Its scientifically known that the earth is surrounded by a layer of atmospheric air . this layer causes pressure which increases as we get closer to the sea level, while it decreases as we ascend above sea level. Decrease in the amount of oxygen in above in high altitudes leads to a decrease in resistance when the body moves as the resistance to air increases during the body movement and this can be noticed in the sports activities of fast running, floating and jumping. The difficulty in performing the physical activates increases in middle and high altitudes due to ( the increases in solar radiation, the increase in air ionization degree, the change of humidity and, heat, the decrease in the atmospheric pressure according to the decrease in the oxygen pressure.

Training in the high altitudes (low atmospheric pressure) depends on the changes that take place in the body systems (physiological and biochemical changes that result from the exposure to climate changes that characterize the cities and places that lie above sea level .

Athletes in the high altitudes ( low atmospheric pressure ) are exposed to some healthy problems, known as, attitude sickness, the symptoms of this sickness are characterized by a headache, dyspnea, sea sickness, and insomnia . these symptoms don't threaten life, but it affect the level of performance several days and weeks, and they rarely change into psychological symptoms called, Edema, The limits of these diseases according to the individuals attribute that to weakness in respiration and ventilation processes.

\section{The problem and importance of the study}

The study problem is represented by the limited molecular oxygen pressure which is attributed to the atmospheric pressure which the air pressure at the sea level reaches $670 \mathrm{~mm}$, this air pressure decreases as we ascend above sea level, while it increase as we descend below sea level and reach (1070)mm at (-300m) below sea level (Al- Bataineh, 2008). According to this variation, many physical changes appear in the high and low atmospheric pressure areas within the Jordanian environment . 


\section{$\triangle$ Macrothink}

The two researchers of this study wonder whether the difference in the atmospheric pressure is attributed to the variation of the Jordanian environment . therefore, this study with its abstract numbers provides us with values for the boy functional variables, which reflect the physical state of athletes during training in the different atmospheric pressure environment, thus this this study aims at identifying the impact atmospheric pressure areas within the Jordanian environment on some physiological variables for runners .

\section{The study objectives:}

This study aims at identifying:

-The impact of the difference between the high and low atmospheric pressure areas within the Jordanian environment on some physiological variables for runners.

-The variation between the high and low atmospheric pressure areas within the Jordanian environment on some physiological variables ( estimating maximal oxygen consumption , estimating rate of energy expenditure, and hemoglobin, vital capacity), for runners .

\section{The study questions}

This study aims at answering the following questions:

-The first questions: Is there an impact for the difference between high and low atmospheric pressure areas within the Jordanian environment on some physiological variables for runners? - The second question:

Is there a distinction in the an impact for the difference between high and low atmospheric pressure areas within the Jordanian environment on some physiological variables ( estimating maximal oxygen consumption, estimating rate of energy expenditure, and hemoglobin ,vital capacity), for runners .

\section{*Literature review (previous studies)}

-First: studies that are related to low lands:

Adel and others (1992) conducted a study that aimed at identifying endurance performance below sea level. The study sample consisted of (21) endurance athletes for long distances. (One and a half miles time, exercise endurance with affixed bike, heart beats rate ). The study conducted that one and a half miles time was better in the Dead Sea in comparison with Amman and Aqaba. The study results also showed that endurance with the fixed bike was better both the Dead Sea and Aqaba in comparison with Amman. The study results also showed that there were statistically significant differences with regard to the variable of heart beats rate in favor of the measurement which were conducted in the Dead Sea and Aqaba.

This study amid at comparing the impact of environment variation below and above sea level on some physiological variables for runners. The study sample consisted of two groups. The first is the training groups below sea level which consisted of (8) athletes and the secand is the training groups above

sea level which also consisted of (8) athletes. The study included the following physiological variables (predicting the value of V02ma* predicting rate of energy expenditure, heart beats rate, systolic and diastolic pressure, hemoglobin, vital capacity and temperature .

The study concluded that there was an improvement in the measurement result which were 
conducted below sea level with regard to the variables of (estimating the value of V02ma*(estimating rate of energy expenditure, blood pressure, and vital capacity) in comparison with the measurement which were conducted above sea level the study reslts also showed that there was an improvement in the measurement result which were conducted above sea level with regard to the variables of (predicting the value of V02ma* predicting rate of energy expenditure, and vital capacity) in comparison with the measurement which were conducted above sea level for the training groups of (above sea level).

\section{*Second : Similar studies}

Studies in heights

Both ( Mellrowic and Meller U.A1970)conducted a study that aimed at identifying the impact of a proposed training program for 4 weeks when training at the height of $2000 \mathrm{~m}$ above sea level. The study sample consisted of (22) endurance athletes for long distances . the study included the functional variables of (V02MAX,heart beats rate, and hemoglobin ). The study concluded that there were statistically significant differences with regard to the variables of (V02MAX, hemoglobin in favor of training in the heights .

Both *(Liesen and Hollmann,1972) conducted a study that aimed at identifying the impact of a proposed training process in the heights on some physiological functions for two weeks and the heights ranged between 1950 and 2800 metres above sea level. The study sample consisted of (6) endurance athletes of long distances. The study included the functional variables of (V02MAX,blood volume hemoglobin, blood oxygen saturation level, blood sugar .

The study concluded that after six day from returning back to the sea level . there was an increase in the variables of (V02MAX,blood volume hemoglobin).

The study result also showed a decrease in the blood oxygen saturation level when training in the heights.

Mohammad (1989) conducted a study that aimed at identifying the physical fitness in the high altitudes (Al-Sulaimaniah) in comparison with the areas at sea level (Al- Anbar). The study sample consisted of (2422) students . the study included the physical variables of broad jump, speed, cardio vascular endurance, and flexibility ). The study conducted that the student who live in the heights the medicine ball, broad jump, and speed. The study result also concluded that(Al- Anbar) students were excellent with regard the variables of cardio vascular endurance, and flexibility.

Khribet ,Mahdi (1990) conducted a study that aimed at identifying the impact of altitude above sea level on some physiological characteristics for footballers, The study sample consisted of (25) footballers from Iraq national team that sheres in the training camp in Brazil. The included the functional variables of rate of heart beats, systolic pressure , breathing times, heart capacity, lung muscles capacity. Study concluded that there were statistically significant differences with regard to the variable rate of heart beats. The study result also showed no statistically significant differences with regard to the variable, systolic pressure, heart capacity, breathing times, capacity of lung muscles.

Hellemans , (1991), conducted a study that aimed at identifying the artificial heights through hypoxic room, and their impact on some physiological variables . The study sample 
consisted of (8) endurance athletes. The study included the functional variables ( blood plasma, rate heart beats ,hemoglobin). The study result also concluded that there were statistically significant differences with regard to the variable blood plasma, rate heart beats ,hemoglobin favor of the internal training groups in hypoxic rooms.

Huang and others (1992) conducted a study that aimed at identifying the impact of living in heights (low atmospheric pressure) and training in the low lands (high atmospheric pressure) and the exposure to hypoxic on some physiological variables The study sample consisted of (28) athletes. The study included the variables of (V02MAX, rate heart beats, blood pressure). The study concluded that there was an evident improvement with regard to the variables of(V02MAX, rate heart beats, blood pressure in favor of the hypoxic groups and the groups which live in the heights and got training at the sea level.

Abu Azzam (1993) conducted a study that aimed at identifying the physical fitness level for the female students in the heights and lowlands. The study sample consisted of (214) female students. The study included the physical variables of ( thickness of fat large ,bending the trunk to the front test sit up test, running test, walking 1609 meters). The study concluded that the lowlands students were better than the heights students in all the tests expect for bending the rank it the front test.

(Kong and Liu 1994), ) conducted a study that aimed at identifying the impact of the various atmospheric, through height - simulating rooms in which the atmospheric and humidity are adjustable. The study sample consisted of(15) endurance athletes The study included the functional variables of(V02MAX vital Capacity blood pressure). The study concluded that there was an evident improvement with regarding to the variables of (V02MAX vital Capacity blood pressure)in favor of the training in height - simulating rooms.

(Kobayshi, 1945) conducted a study that aimed at identifying the training system in hypoxic and training in the heights. The study sample consisted of (23) Japanese runners. The study included the functional variables of (V02MAX vital Capacity). The study concluded that there was a clear improvement for the variables of (V02MAX vital Capacity) in favor of the training system in hypoxic and training in the heights.

(Feng,2000) conducted a study that aimed at identifying the impact of falls heights, living in the heights(low atmospheric pressure) and training in the low lands (at sea level) and living in the low lands and training in the heights The study sample consisted of(24)athletes of long distances athletes The study included the functional variables of (V02MAX, rate heart beats, V02MAX, rate energy expenditure) The study concluded that there was an evident improvement with regarding to the variables of(V02MAX, rate heart beats, V02MAX, rate energy expenditure) in favor of the training groups which lived heights but trained (at sea level) .

(Zaruby, 2002), conducted a study that aimed at identifying the improvement of performance level at sea level through using the strategy of

\section{*Methodology and study methods}

- The study method: The descriptive method was used by following the scientific steps and procedures of the survey study due to its suitability to the nature of this study. 


\section{Macrothink}

\section{*The study society and sample:}

The study society:

The study society consisted of all the (130) endurance athletes ( middle and long distances running ) who are registered in the Jordanian federation for athletics.

*The study sample:

The study sample consisted of (16) athletes (middle and long distances running), who were divided into two training groups:

- High atmospheric pressure: (8) athletes.

- Low atmospheric pressure: (8) athletes.

Table (1) illustrates the arithmetic means, standard deviations, " $Z$ " calculated values between the two training groups with regard to the variables of length, weight, age, and training age.

\begin{tabular}{|c|c|c|c|c|c|}
\hline Variables & $\begin{array}{l}\text { Training } \\
\text { Groups }\end{array}$ & $\begin{array}{l}\text { Arithmetic } \\
\text { Mean }\end{array}$ & $\begin{array}{l}\text { Standard } \\
\text { Deviation }\end{array}$ & "Z" Value & $\begin{array}{l}\text { Significance } \\
\text { Level }\end{array}$ \\
\hline \multirow[t]{2}{*}{ Length } & $\begin{array}{l}\text {-High } \\
\text { atmospheric } \\
\text { pressure - }\end{array}$ & 157.75 & 14.47 & \multirow[t]{2}{*}{1.47} & \multirow[t]{2}{*}{0.140} \\
\hline & $\begin{array}{l}\text { Low } \\
\text { atmospheric } \\
\text { pressure }\end{array}$ & 167.38 & 7.39 & & \\
\hline \multirow[t]{2}{*}{ Weight } & $\begin{array}{l}\text {-High } \\
\text { atmospheric } \\
\text { pressure- } \\
\text { Low }\end{array}$ & 51.63 & 10.06 & \multirow[t]{2}{*}{0.15} & \multirow[t]{2}{*}{0.875} \\
\hline & $\begin{array}{l}\text { atmospheric } \\
\text { pressure }\end{array}$ & 51.38 & 8.68 & & \\
\hline \multirow[t]{2}{*}{ Age } & $\begin{array}{l}\text {-High } \\
\text { atmospheric } \\
\text { pressure - }\end{array}$ & 20.75 & 1.39 & \multirow[t]{2}{*}{0.06} & \multirow[t]{2}{*}{0.951} \\
\hline & $\begin{array}{l}\text { Low } \\
\text { atmospheric } \\
\text { pressure }\end{array}$ & 20.50 & 0.76 & & \\
\hline \multirow[t]{2}{*}{ Training Age } & $\begin{array}{l}\text {-High } \\
\text { atmospheric } \\
\text { pressure } \\
\text {-Low }\end{array}$ & 6.13 & 0.99 & \multirow[t]{2}{*}{0.32} & \multirow[t]{2}{*}{0.744} \\
\hline & $\begin{array}{l}\text { atmospheric } \\
\text { pressure }\end{array}$ & 6.38 & 1.30 & & \\
\hline
\end{tabular}

*"Z" tabulated value when $(0.05)=1.96$

Table (1) illustrates the arithmetic means, the standard deviation, " $Z$ " calculated value between the two training groups with regard to the variables of the variables of length, weight, 
age , and training age. " $Z$ " calculated value and its accompanying significant level shows that were no statistically significant differences between the two training groups, as all the values of the significance level were more than (0.05) which means that the two groups identical for these measurements.

*Table (2) the results of Kolmogorov - Simrnov test between the two training groups for the study variables which were measured in the areas of high and low atmospheric pressure.

\begin{tabular}{|l|l|l|l|l|}
\hline & \multicolumn{3}{|l|}{ High atmospheric pressure } & \multicolumn{2}{l|}{ low atmospheric pressure } \\
\hline & "Z” value & $\begin{array}{l}\text { significant } \\
\text { level }\end{array}$ & “Z” value & $\begin{array}{l}\text { significant } \\
\text { level }\end{array}$ \\
\hline $\begin{array}{l}\text { Maximal oxygen } \\
\text { consumption }\end{array}$ & 0.75 & 0.627 & 0.25 & 1 \\
\hline Rate of energy expenditure & 0.75 & 0.627 & 0.25 & 1 \\
\hline Hemoglobin & 0.50 & 0.964 & 0.50 & 0.964 \\
\hline Vital capacity & 0.75 & 0.627 & 0.75 & 0.627 \\
\hline
\end{tabular}

*"Z" tabulated value when $(0.05)=1.96$

Table (2) illustrates the result of Kolmogorov-smirnov test between the two training groups for the study variables which were measured in the high and low atmospheric pressure. By reviewing " $z$ " calculated value and the accompanying significance level we notice that all the values of significance level were more than (0.05) for all the study variables (maximal oxygen consumption, hemoglobin, rate of energy expenditure and vital capacity ), which indicates that the frequency distribution of the two training groups data was similar. Therefore, the validity of the conclusion about the convergence of the two group's data when the measurement was conducted in the areas of high atmospheric pressure, and when it was also conducted in the areas of low atmospheric pressure

\section{*The study variables}

* First: the independent variables which include:

- The areas of atmospheric pressure:

a- The areas of low atmospheric pressure.

b- The areas of high atmospheric pressure.

* Second: The dependent variables which include:

1- Estimating the maximal oxygen consumption.

2- - Estimating the rate of energy expenditure.

3- Hemoglobin.

4- Vital capacity.

*The study tools and tests: 


\section{Macrothink}

The following study tools and tests were used:

1- Running distance of one and a half miles in order to estimate the maximal oxygen consumption.

2- A device for measuring the vital capacity (spirometer).

3- A device for measuring the weight.

4- A device for measuring the length.

5- Clock timers.

*The statistical methods: a number of statistical methods were used in order to answer the questions of the study (Arithmetic means, standard deviations, mann.whitney test, and the results Kolmogorov-smirnov test)

\section{*The scientific coefficients of the tests.}

-The validity and reliability of tool: A number of tests and tools, which proved validity and reliability at measurement in the field of sports, were used. These tests are considered as standardized tests and the validity of these tests became evident, besides depending on some views of specialists in field.

*The steps for conducting the study (the field procedures for the research (study).

- Forecasting equations: The two researchers used some specific forecasting equations in order to prepare the study, as follow:

-The test of running for one and a half miles was selected (hazza'2008,), the following forecasting equation was used to estimate the maximal consumption :

The consumption $(\mathrm{mm} / \mathrm{kg}$ aminnte $)=(483 / 1.5$ miles running time $)+3.5$.

-(Weir) forecasting equation was selected in order to estimate energy expenditure during the physical activity (Hazza', 2008) :

Energy expenditure (Kilo calories) $=$

Oxygen consumption (by liter) $*(3.9+(1.1 *$ respirator quotient $)$

\section{- Organizational procedures}

The study was conducted as follow:

-The two researchers and others took the physical measurements (length, weight, laboratory biochemical test ( blood hemoglobin)).

- The test of running for one and a half miles was conducted on the study sample in a special track

- The previous tests and measurements were conducted in the areas of (high and low atmospheric pressure).

-The climate changes were taken into account in these two areas: (humidity, temperature, winds speed).

\section{*Introducing and discussing the study results:}

This study aims at answering the following questions:

The first question: is there an impact for the difference between the areal of low and high atmospheric pressure in the Jordanian environment on some physiological variables for runners? 
- Table (3) illustrates the arithmetic mean, the standard deviation for the study variables which were measured in the areas of low atmospheric pressure for the two training groups.

\begin{tabular}{|c|c|c|c|c|c|}
\hline \multirow[t]{2}{*}{ variables } & \multirow[t]{2}{*}{$\begin{array}{l}\text { Measurement } \\
\text { place }\end{array}$} & \multicolumn{2}{|c|}{$\begin{array}{l}\text { Training groups } \\
\text { high atmospheric } \\
\text { pressure }\end{array}$} & \multicolumn{2}{|c|}{$\begin{array}{l}\text { Training group low } \\
\text { atmospheric pressure }\end{array}$} \\
\hline & & $\begin{array}{l}\text { Arithmetic } \\
\text { means }\end{array}$ & $\begin{array}{l}\text { Studded } \\
\text { deviation }\end{array}$ & Arithmetic means & $\begin{array}{l}\text { Studded } \\
\text { deviation }\end{array}$ \\
\hline $\begin{array}{l}\text { Maximal } \\
\text { Oxygen } \\
\text { consumption }\end{array}$ & $\begin{array}{l}\text { low } \\
\text { atmospheric } \\
\text { pressure }\end{array}$ & 59.04 & 8.12 & 59.22 & 7.49 \\
\hline $\begin{array}{l}\text { Rete of } \\
\text { Energy } \\
\text { expenditure }\end{array}$ & $\begin{array}{l}\text { low } \\
\text { atmospheric } \\
\text { pressure }\end{array}$ & 275.64 & 37.83 & 276.55 & 34.99 \\
\hline hemoglobin & $\begin{array}{l}\text { low } \\
\text { atmospheric } \\
\text { pressure } \\
\end{array}$ & 14.01 & 1.20 & 14.15 & 1.35 \\
\hline Vital capacity & $\begin{array}{l}\text { low } \\
\text { atmospheric } \\
\text { pressure }\end{array}$ & 7.75 & 11.96 & 4 & 0.92 \\
\hline & & & & & \\
\hline
\end{tabular}

Table (3) illustrates the values of arithmetic mean and standard deviation for the study variables in the areas of low atmospheric pressure. For the two training groups. After reviewing the values of arithmetic means which were conducted in the areas of low atmospheric pressure, it becomes evident that there is a priority for the measures which were conducted on the training groups of low atmospheric pressure in comparison with the other groups with regard to the variables of ( maximal oxygen consumption, rate of Energy expenditure, and hemoglobin ), as the arithmetic mean for the variable of rate of maximal oxygen consumption was (59.22), the arithmetic mean for the variable rate of energy expenditure was (276.55), while the arithmetic mean of hemoglobin was (14.15)

The measurements which were conducted on the training groups of the high atmospheric pressure were better than those of other group, with regard to the variable of vital capacity, Where the arithmetic mean of vital capacity was about (7.75).

The two researchers attribute the priority of the measurement which was conducted on the training groups of low atmospheric pressure to the adaptation of this group to the low 


\section{I Macrothink}

atmospheric pressure. The adaptation to the decrease in molecular oxygen pressure motivates the pulmonary vesicles to adapt with the low oxygen pressure in the pulmonary vesicles affects the ratio of saturation with hemoglobin (Hazza' 1994) as when the molecular pressure decrease, the pulmonary vesicles saturation with oxygen also decreases. Therefore, hemoglobin ratio increases in the areas of low atmospheric pressure in order to compensate for the saturation ratio which decreases as a result of the decrease in molecular oxygen pressure in pulmonary vesicles. This study corresponds to the study of (Hellemans, 1991), which concluded to that there were statistically significant differences for the variable of hemoglobin in favor of the interval training groups in hypoxic rooms.

*Table (4) illustrates the arithmetic means and the standard deviations for the study variables which were measured in the areas training of high atmospheric pressure for the two training groups.

\begin{tabular}{|l|l|l|l|l|l|}
\hline Variables & Measurement place & \multicolumn{2}{|l|}{$\begin{array}{l}\text { Training group high } \\
\text { atmospheric pressure }\end{array}$} & $\begin{array}{l}\text { Training group low } \\
\text { atmospheric pressure }\end{array}$ \\
\hline & $\begin{array}{l}\text { Arithmetic } \\
\text { mean }\end{array}$ & $\begin{array}{l}\text { Standard } \\
\text { deviation }\end{array}$ & $\begin{array}{l}\text { Arithmetic } \\
\text { mean }\end{array}$ & $\begin{array}{l}\text { Standard } \\
\text { deviation }\end{array}$ \\
\hline $\begin{array}{l}\text { Maximal oxygen } \\
\text { consumption } \\
\text { pressure }\end{array}$ & $\begin{array}{l}\text { high atmospheric } \\
70.84\end{array}$ & 6.07 & 66.75 & 3.67 \\
\hline $\begin{array}{l}\text { rate of Energy } \\
\text { expenditure }\end{array}$ & $\begin{array}{l}\text { high atmospheric } \\
\text { pressure }\end{array}$ & 330.72 & 28.21 & 311.70 & 17.14 \\
\hline $\begin{array}{l}\text { hemoglobin } \\
\text { high atmospheric } \\
\text { pressure }\end{array}$ & 13.56 & 1.16 & 13.70 & 1.31 \\
\hline vital capacity & $\begin{array}{l}\text { high atmospheric } \\
\text { pressure }\end{array}$ & 330.72 & 28.21 & 311.70 & 17.14 \\
\hline
\end{tabular}

Table (4) illustrates the values of arithmetic mean and standard deviation for the study variables in the areas of high atmospheric pressure .for the both training groups reviewing the average values of measurements which were conducted in the areas of the high atmospheric pressure, we can see that is apriority for the measurements which were conducted on the training groups of high atmospheric pressure with regard to the variables of( maximal oxygen consumption, rate of Energy expenditure, and vital capacity ), as the arithmetic mean for the variable of rate of maximal oxygen consumption was (70.84),

the arithmetic mean for the rate of energy expenditure was (330.72)and the arithmetic mean for vital capacity also (330.72)while there was priority of the measurement which was conducted on the training groups of low atmospheric pressure with regard to the variable of (hemoglobin), as arithmetic mean for( hemoglobin) was (13.70)

The apriority for the measurements which were conducted on the training groups of high atmospheric pressure can be attributed to a number of climate changes in the areas of high atmospheric pressure, as the increase of molecular oxygen pressure leads to more saturation for 
oxygen in the blood and that improve the tissues capacity for maximal oxygen consumption. Energy expenditure relates directly to the ratio of oxygen that reaches the muscles, which improve due to increase of air pressure and molecular oxygen pressure that exists in the areas of below sea level, and thus improves oxygen rates in tissues. The increase in intensity and air pressure in the low areas also improves the vital capacity.

*The second question: Is there a distinction in the impact of difference between the areas of high and low atmospheric pressure within the Jordanian environment on some physiological variables (estimating the maximal oxygen consumption, the rate energy expenditure, hemoglobin, and vital capacity for runners?

Table (5) : the results of Mann.whitney test between both training groups for the study variables which were measured in the areas of high atmospheric pressure.

*"Z" tabulated value when $(0.05)=1.96$

Table (5) illustrates the result of Mann.whitney test between the two training groups for the

\begin{tabular}{|c|c|c|c|c|c|c|c|}
\hline variables & training group & $\begin{array}{l}\text { Ranks } \\
\text { total }\end{array}$ & $\begin{array}{l}\text { Ranks } \\
\text { number }\end{array}$ & $\begin{array}{l}\text { Ranks } \\
\text { mean }\end{array}$ & $\begin{array}{l}\text { "Z" } \\
\text { value }\end{array}$ & $\begin{array}{l}\text { Significance } \\
\text { level }\end{array}$ & Significance \\
\hline \multirow[t]{2}{*}{$\begin{array}{l}\text { maximal oxygen } \\
\text { consumption }\end{array}$} & $\begin{array}{l}\text { high atmospheric } \\
\text { pressure }\end{array}$ & 79.50 & 8 & 9.94 & \multirow[t]{2}{*}{1.20} & \multirow[t]{2}{*}{0.227} & \multirow[t]{2}{*}{ non Significance } \\
\hline & $\begin{array}{l}\text { low atmospheric } \\
\text { pressure }\end{array}$ & 56.50 & 8 & 7.06 & & & \\
\hline \multirow[t]{2}{*}{$\begin{array}{l}\text { rate energy } \\
\text { expenditure }\end{array}$} & $\begin{array}{l}\text { high atmospheric } \\
\text { pressure }\end{array}$ & 79.50 & 8 & 9.94 & \multirow[t]{2}{*}{1.20} & \multirow[t]{2}{*}{0.227} & \multirow[t]{2}{*}{ non Significance } \\
\hline & $\begin{array}{l}\text { low atmospheric } \\
\text { pressure }\end{array}$ & 56.50 & 8 & 7.06 & & & \\
\hline \multirow[t]{2}{*}{ Hemoglobin } & $\begin{array}{l}\text { high atmospheric } \\
\text { pressure }\end{array}$ & 64 & 8 & 8 & \multirow[t]{2}{*}{0.42} & \multirow[t]{2}{*}{0.674} & \multirow[t]{2}{*}{ non Significance } \\
\hline & $\begin{array}{l}\text { low atmospheric } \\
\text { pressure }\end{array}$ & 72 & 8 & 9 & & & \\
\hline \multirow[t]{2}{*}{ Vital capacity } & $\begin{array}{l}\text { high atmospheric } \\
\text { pressure }\end{array}$ & 61 & 8 & 7.63 & \multirow[t]{2}{*}{0.73} & \multirow[t]{2}{*}{0.462} & \multirow[t]{2}{*}{ non Significance } \\
\hline & $\begin{array}{l}\text { low atmospheric } \\
\text { pressure }\end{array}$ & 75 & 8 & 9.38 & & & \\
\hline
\end{tabular}

study variables which were measured in the areas of high atmospheric pressure. the values of the significance level that accompanies " $Z$ calculated value show that there were no statistically significant differences for the study variables between the two training groups, as all the calculated values were more than $(0.05)$, which indicates that there were no statistically significant differences for the study variables (maximal oxygen consumption, the rate energy expenditure, hemoglobin, and vital capacity) 


\section{Ml Macrothink}

Both researchers attribute not having significant differences between the two training groups to the nature of the low areas (high atmospheric pressure) where the measurements were conducted, as these areas are characterized by their high temperature. The atmospheric pressure decreases as the temperature increases, because the air heats and expands, so that some of this air transmits to another area, and thus the weight of air decreases, leading to a decreases in pressure, and this could be the reason for not having evident differences. This could also be attributed to the decline below sea level $(-410 \mathrm{~m})$ in which the air pressure is (1070mm), so it isn't sufficient to cause physical changes at the level of molecular oxygen pressure which is supposed to increases the oxygen pressure in the pulmonary vesicles, and thus increases the ratio of oxygen consumption in the arterial blood .

*Table (6) : The result of Mann.whitney test between the both training groups for the study variables which were measured in the areas of high atmospheric pressure..

\begin{tabular}{|c|c|c|c|c|c|c|c|}
\hline variables & training group & $\begin{array}{l}\text { Ranks } \\
\text { total }\end{array}$ & $\begin{array}{l}\text { Ranks } \\
\text { number }\end{array}$ & $\begin{array}{l}\text { Ranks } \\
\text { mean }\end{array}$ & $\begin{array}{l}\text { "Z" } \\
\text { value }\end{array}$ & $\begin{array}{l}\text { Significance } \\
\text { level }\end{array}$ & Significance \\
\hline \multirow[t]{2}{*}{$\begin{array}{l}\text { maximal } \\
\text { oxygen } \\
\text { consumption }\end{array}$} & $\begin{array}{l}\text { High } \\
\text { atmospheric } \\
\text { pressure. }\end{array}$ & 66 & 8 & 8.25 & \multirow[t]{2}{*}{0.21} & \multirow[t]{2}{*}{0.834} & \multirow[t]{2}{*}{$\begin{array}{l}\text { Non } \\
\text { Significance }\end{array}$} \\
\hline & $\begin{array}{l}\text { low } \\
\text { atmospheric } \\
\text { pressure }\end{array}$ & 70 & 8 & 8.75 & & & \\
\hline \multirow[t]{2}{*}{$\begin{array}{l}\text { rate energy } \\
\text { expenditure }\end{array}$} & $\begin{array}{l}\text { High } \\
\text { atmospheric } \\
\text { pressure. }\end{array}$ & 66 & 8 & 8.25 & \multirow[t]{2}{*}{0.21} & \multirow[t]{2}{*}{0.834} & \multirow[t]{2}{*}{$\begin{array}{l}\text { Non } \\
\text { Significance }\end{array}$} \\
\hline & $\begin{array}{l}\text { low } \\
\text { atmospheric } \\
\text { pressure }\end{array}$ & 70 & 8 & 8.75 & & & \\
\hline \multirow[t]{2}{*}{ Hemoglobin } & $\begin{array}{l}\text { High } \\
\text { atmospheric } \\
\text { pressure. }\end{array}$ & 64 & 8 & 8 & \multirow[t]{2}{*}{0.42} & \multirow[t]{2}{*}{0.674} & \multirow[t]{2}{*}{$\begin{array}{l}\text { Non } \\
\text { Significance }\end{array}$} \\
\hline & $\begin{array}{l}\text { low } \\
\text { atmospheric } \\
\text { pressure }\end{array}$ & 72 & 8 & 9 & & & \\
\hline \multirow[t]{2}{*}{ Vital capacity } & $\begin{array}{l}\text { High } \\
\text { atmospheric } \\
\text { pressure. }\end{array}$ & 61 & 8 & 7.63 & \multirow[t]{2}{*}{0.73} & \multirow[t]{2}{*}{0.462} & \multirow[t]{2}{*}{$\begin{array}{l}\text { Non } \\
\text { Significance }\end{array}$} \\
\hline & $\begin{array}{l}\text { low } \\
\text { atmospheric }\end{array}$ & 75 & 8 & 9.38 & & & \\
\hline
\end{tabular}


Table (6): illustrates the result of Mann.whitney test between the two training groups for the study variables which were measured in the areas of low atmospheric pressure .where the values of the significance level that accompanies " $Z$ " calculated value show that there were no statistically significant differences with regard the study variables between the two training groups, As all the calculated values were more than (0.05), which indicates that there were no statistically significant differences between the both training groups. The study variables (maximal oxygen consumption, the rate energy expenditure, hemoglobin, and vital capacity)

Both researchers attribute not having statistically significant differences between the two training groups with regard to the study variables (maximal oxygen consumption, the rate energy expenditure, hemoglobin, and vital capacity) which were measured in the areas of low atmospheric pressure, to the nature of these high areas which range between (777-1400) meters above sea level, as this altitudes that are used in the ideal training processes ( middle altitudes ) that range between 1800 and 2400 meters, which are considered as the most suitable for the altitudes training .

The main problem of athletes in these altitudes derives from the limited molecular oxygen pressure due to the low atmospheric pressure, which causes a decrease in absorbing the oxygen, and thus, reduces air energy supplies to the available altitudes in which the measurements were conducted . knowing that the measurements which were taken in the high atmospheric pressure were at (-410) metres below sea level . While the measurements which were taken in the low atmospheric pressure were taken at a height that ranged between (777-1400) meters which means that the difference between these two areas range between (1800-1900) meters .

\section{Conclusions}

In the light of the study results, the following Conclusions were cited .

1-The study result showed that there was apriority for the measurements which were conducted on the training group of the low atmospheric pressure in comparison with the other group with regard to the variables of (maximal oxygen consumption, the rate energy expenditure, and hemoglobin).

2-The result of the study showed that there was apriority for the measurements which were conducted on the training group of the high atmospheric pressure in comparison with the other group with regard to the variables of (maximal oxygen consumption, the rate energy expenditure, vital capacity).

3- The result of the study showed that there were no statistically significant differences between the both training groups. With regard The study variables of (maximal oxygen consumption, the rate energy expenditure, hemoglobin, and vital capacity) which were measured in the areas, of high and low atmospheric pressure. 


\section{MIl Macrothink}

\section{*RECOMMENBATIONS*}

In the light of the study results, the study recommends about:

1-Building sports facilities that simulate that the areas of low atmospheric pressure, due to the expected role that the factors would play in improving some physiological variables.

2- Conducting a study that includes a training program that aims at the functional for the internal systems in the areas of low atmospheric pressure.

3- Conducting a study that includes areas of higher atmospheric pressure altitudes than those in the recant study in order to get more precise result for the low atmospheric pressure.

\section{*Reference*}

- Thunaibat, Bakir Suleiman (2010). A comparative Study about the impact the impact of the difference of the training environment (above or below sea level) on some physiological variables for endurance athletes, doctorate thesis, the university of Jordan effort physiology : Theoretical basis and laboratory procedures the physiological measurements, Al- Riyadh -king Saud University.

- Al- Hazza' Hazza' Bin Mohammad (2009) ; thermoregulation during physical effort in the hot atmospheres, seminar proceedings of adaptation for physical training in the hot atmospheres in the cooperation council for the Arab States of gulf

- AL- Hazza' Hazza' Bin Mohammad (2007) thermoregulation and Compensating liquids during physical effort of the human being. Al- Riyadh Saudi sport medicine association.

- AL- Hazza' Hazza' Bin Mohammad (2005) measuring the physical activity and energy expenditure of human being a brief review, the proceedings of the second conference of obesity and physical activity, The Arab journal for food and nutrition, Al- Riyadh 6(13):26-50 .

- AL- Hazza' Hazza' Bin Mohammed (1994) compensating liquids during physical effort the proceedings of the seventh training course in sports medicine, Al- Riyadh Saudi sport medicine association.

- AL- Hazza' Hazza' Bin Mohammed (1994) biochemistry of physical effort, the journal of Physical Education Sciences and Sport . Al-Manamah, Al- Bahrain Sport institute . volume (4) page (60-62).

- Al- Hazza' Hazza’ Bin Mohammad (1993) ; thermoregulation during physical effort in the hot weather ( the cultural series for Saudi association for physical fitness.

- AL- Hazza' Hazza' Bin Mohammed(2005) heights and the physical performance , physiological considerations, Al- Riyadh, the research center in the faculty of Education, deanship of academic research at the University of king Saud

- AL- Hazza' Hazza' Bin Mohammed(2005), thermo injuries that result from the physical effort effort in the hot weather, Al- Riyadh, the research center in the faculty of Education, deanship of academic research at the University of king Saud .

- AL- Hazza' Hazza' Bin Mohammed(2002), sports medicine, its concept, aspect, activities , Al- Riyadh , the research center in the faculty of Education, deanship of academic research at the University of king Saud . 
- Ismail Sate' (2008) the impact of heights and the physical level, Iraqi academy,www.Iraqacad.org .

- Abu Azzam, Hayam (1993), the physical fitness level for the elementary education stage in the heights and low lands " a comparative study |" unpublished master thesis .

- Mohammad ,Ibrahim , (1989), measuring the level of physical growth and physical fitness for the age (13-16) in order to compare the students result in the governorates of Al-AnbarAND Al-Suleimaniah unpublished master thesis, University of Baghdad, Baghdad ,Iraq.

- Khribet ,Mahdi (1990) The impact of altitude above sea level on some physiological characteristics for footballers, unpublished master thesis, University of Baghdad, Baghdad ,Iraq.

- Habib , Ibrahim, (2007), desiccation of the dead sea ( red sea canal), researches and arab studies institute.

- Baha' Al-din Salamah (2000) sport physiology and physical fitness (blood lactate ), Arab thought foundation, Cairo.

- Sa'ad Al-deen , Mohammad Sameer (1996), The impact of physical effort on body thermoregulation responses with the differences in temperature and humidity, unpublished doctorate thesis, University of Asyat, Asyat Egypt.

- Omar , Omar Shukri ( 1994 ) thermo balance and its impact on some physiological and biochemical variables for some practitioners of the physical activity the University of Asyat.

- Middle East (2005), heights sickness takes place at climbing and causes health problems , AlRiyadh, volume 9753 .

- Al- Bayati , Maher (2005), The impact of variant temperature on some functional variables for footballers, the journal of physical fitness sciences, volume (2).

- Al-Gamlas , Abeer and Abdulqader Abduljaleel, (2007), practicing sport in the different topographies and its physiological impact. The Saudi Journal for sport medicine. 9(2),(123-127).

- AL-Khaledi, Sultan Sharida , (1990) Organs functions and the physical training , Al- Riyadh The Saudi Arabian association for sport medicine.

- Abdullatif ,Zina (1990), the functional changes during the physical effort under the condition of different temperatures, unpublished master thesis, University of Baghdad, Baghdad .

- Abdulfattah , AbuAl-ela (2003) training and sports physiology , Cairo ,Arab Thought foundation .

- Uthman ,Mohmmad Abdulghami (2000), the training and adaptation load - the biophsiological responses to the training laod pressure between theory and applied fact -Cairo ,Arab Thought foundation .

- Uthman ,Mohmmad Abdulghami ,(1994), motor learning and physical training ,Kuwait, Dar $\mathrm{Al}$-Qalam .

- Al- Maghrabi, Salah Al-din (1999), the human being and the high altitudes, London, Royal College of physicians .

- Kamal, Khalid Salah Al-din (2006), function of the physical effort organs , Al-Riyadh , deanship of library affairs, the University of king saud .

- Al- Bataineh, Mohammad Said Ali (2008), the weather forecasting between theory and application, Amman, meteorological department. 


\section{Macrothink}

Journal of Sociological Research

ISSN 1948-5468

2013, Vol. 4, No.2

- Zeytoon ,Ayesh (2008), the human biology, Amman ,Al-Shorok for publishing and distribution.

- Adel, et al (1992), ENDURANCE PERFORMANCE BELOW SEA LEVEL, abhath yarmouk University ,Irbid,Jordan.

- Howley ,Edward and powers scott (2000) Exercise physiology ,International Edition.

- Oroud, Ibrahim ( 2001 ) Evaporation from the dead sea :paet, present and future trends, abhath Yarmouk University.

- Hellemans, John (1997) HIGH ALTITUDE TRAINING SYMPOSIUM, Hong Kong Sports Institute, Hong Kong

- Randall L, Wilber (1993) Current Practices and Future Trends in Altitude Training, United States Olympic Committee.

- Kong, Yang HuZhaowei, Haiping ,Liu (1994) Effects of Hypoxic Training on Aerobic Capacity and Performance, Beijing Sport University, Beijing, China .

- , Jia Huang ,Guoqiang Xiao, Raymond So, Yuen Mei Tse (1992)Effect of LiveHigh-Train-Low and Intermittent Hypoxic Exposure on EPO and Other Blood Parameters, Physical Education Department of South China Normal University Institute of Sports Sciences, Guangdong, China.

- Kobayashi , Kando (1995)Hypoxic Training System and Altitude Training, Department of Sports Science, Tokyo, Japan.

- Feng, Lianshi (2000)A Pilot Experimental Study on Simulated Altitude Training, The Biology Centre, China Institute of Sport Science, Beijing, China .

- Hamlin, Mike(1998)Normobaric Intermittent Hypoxic Training, Lincoln University, Canterbury, New Zealand .

- Li, Weiping (1992)A Study of the Application of Simulated Altitude Training on Elite Endurance Athletes of China, Shandong Sports Science Center, Shandong, China.

- Zaruby , Jeff (2002)"Sleep High-Train low" The Known and Unknown of Intermittent Hypoxic Exposure, Boulder, Colorado, USA. 